Ann. Biol. anim. Bioch. Biophys., I975, 15 (3), 509-516.

\title{
VARIATIONS IN PITUITARY AND BLOOD LH DURING PUBERTY IN THE MALE LAMB. RELATION TO TIME OF BIRTH
}

\author{
M. COUROT, Marie-Madeleine de REVIERS et J. PELLETIER \\ with the technical assistance of Claudine Pisselet, A. Caraty and Cl. Cornu \\ Station de Physiologie de la Reproduction, \\ Centre de Recherches de Tours, I. N.R. A., \\ Nouzilly, 37380 Monnaie
}

\section{SUMIMARY}

\begin{abstract}
Testicular weight, pituitary LH concentration, blood plasma LH were measured in Ile-deFrance lambs born in the sexual season (September) or out of season (February) to see how these characters are modified at puberty.

During the period of low testicular growth, the impuberal period, there was a large increase in pituitary $\mathrm{LH}$ concentration and a significant linear increase in blood plasma $\mathrm{LH}$; the halflife of the latter is the same as in the adult. In the period of rapid testicular growth, the prepubertal and pubertal period, pituitary LH stabilised or decreased according to the season, and blood LH remained at a level lower than that of the peak reached at the end of the preceeding period. Thus spermatogenesis commenced after blood LH reached peak values.
\end{abstract}

In the lamb, a species in which spermatogenesis starts two to three months after birth (Watson, SApsford and McCance, I956 ; Courot, I962; Skinner et al., I968) it has been demonstrated that the impuberal testis is dependent upon pituitary hormones and especially upon $\mathrm{L}_{4} \mathrm{H}$ since hypophysectomy induces testicular weight regression while $\mathrm{LH}$ reverses the effects of this operation (Couror, I970). Thus, it is of interest to know the evolution of the pituitary content and that of the blood plasma levels of this hormone in the lamb during a period including the establishment of spermatogenesis. Such results are reported in the present paper. As the sheep has a well defined sexual season, the work dealt with lambs born either at the end of February or September. 


\section{MATERIAI, AND METHODS}

$$
\text { A. - Animals }
$$

Ile-de-France lambs were raised indoors with their mother under natural daylight duration and progressively weaned at hundred days of age. There were two groups, those born in September, those born in February.

$$
\text { B. - Sampling }
$$

- Pituitary glands were collected at autopsy in the morning from lambs selected according to their body weight as representative of the mean value of the flock. Animals were slaughtered at the ages shown in figure 2 . The glands were immediately dissected, weighed and placed in cold grade A acetone $\left(-\mathrm{I}_{5}{ }^{\circ} \mathrm{C}\right)$. After dehydratation the anterior lobes were dissected free and pooled according to age of animals and season ( 10 to 20 glands per group), powdered and stored at $-15^{\circ} \mathrm{C}$ until assay.

- Testes were weighed at autopsy.

- Blood samples were collected once a week from birth onwards in two groups of lambs, Io born at the end of February and 9 born at the end of September. $5 \mathrm{ml}$ of blood were collected into heparinised syringes by acute jugular venepuncture at 9 a.m. ; blood plasma was immediately separated by centrifugation at $25^{\circ 0} \mathrm{~g}$ at $4^{\circ} \mathrm{C}$ and stored in the frozen state until assay.

$$
\text { C. - Assay }
$$

The concentration of $\mathrm{LH}$ in the anterior pituitary was measured by the OAAD test as modified by PELLETIER (I963). The sensitivity has been established as o.2 $\mu \mathrm{g}$ LH./mg. Results are given in $\mu \mathrm{g}$ NIH-LH-S I I (0.8I NIH-LH-S I) per $\mathrm{mg}$ of anterior pituitary preparation for each group of lambs.

The concentration of blood LH was determined on $3 \times 50 \mu 1$ of plasma by RIA using the double antibody technique (PeLletier et al., I968). The sensitivity has been established as $0.5 \mathrm{ng} \mathrm{LH} / \mathrm{ml}$. Results are given in $\mathrm{ng}$ CNRS-LH-M 3 ( I.8 NIH-LH-SI) per ml of blood plasma. The mean value of the LH concentration in the blood plasma $\left(m \pm s_{e}\right)$ was calculated for each week of age in both groups of lambs; correlation and regression between these parameters were established.

$$
\text { D. - Halt-life of exogenous } \mathrm{LH}
$$

This was calculated in three 50 day old lambs after an acute injection into the jugular vein of purified ovine I3I I-labelled LH (I.5 $\mu$ g CNRS-LH-M 3, I $_{5} \mu \mathrm{Ci} / \mathrm{animal}$ ). Blood samples were taken from the contralateral jugular vein every 5 minutes during the first 30 minutes following injection, and then every i 5 minutes during the next 2.30 hours. The radioactivity of the blood plasma, and that of the immunoprecipitable fraction of the latter by anti-ovine LH antibody in excess was measured. Half-life was estimated in the period of rapid decrease of radioactivity as the time taken for the latter to decrease by half.

\section{RESULTS}

\section{A. - Testicular weight}

Testicular weights are given in text figure I. Growth was low in both groups during the first 80-roo days. It then increased noticeably. Differences between groups of lambs appeared later; the intensive growth of the testis occurred a little earlier in September than in February born animals. After I50 days of age, the 


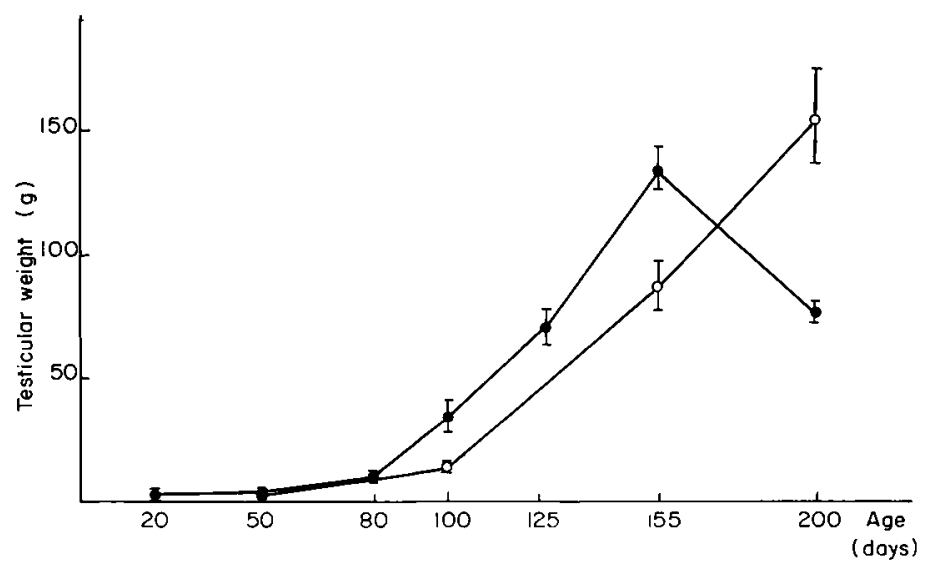

FIG. I. - Increase in testicular weight ( $\left.m \perp s_{e}\right)$ in lambs born in September (- - or February (o-

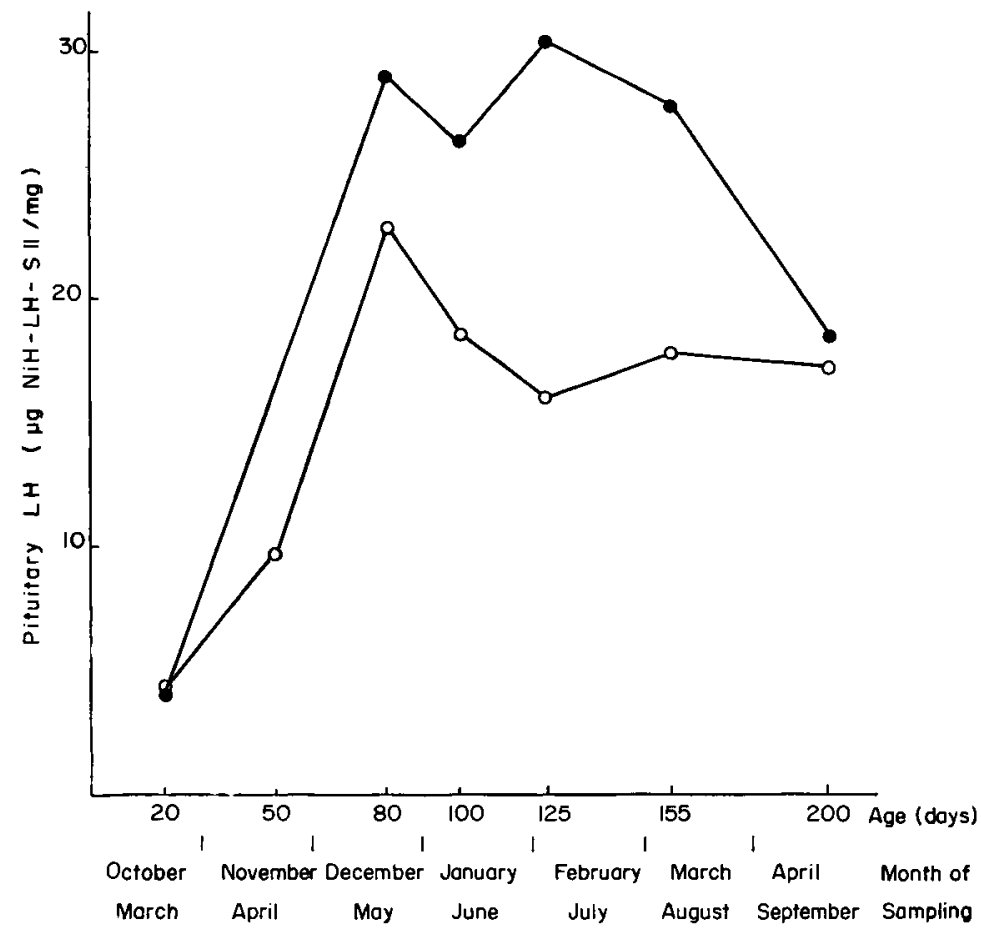

FIG. 2. - Pituitary $L H$ in lambs at different ages

(- born in September; o—— born in February) 
discrepancy in testicular weight in both groups was more evident. By 200 days, the September born lambs showed a statistically significant decrease in testicular weight while the gonads of lambs born in February continued to increase.

\section{B. - Pituitary LH content}

As shown in fig. 2, the $\mathrm{LH}$ concentration of the anterior pituitary tissue increased steeply, 6 to 7 times, from 20 to 80 days of age. After 80 days, the LH concentration in the pituitary was higher in the lambs born in September than in those born in February. It remained consistently higher than that of the $20-50$ day old lambs. According to the weight increase of the pituitary from birth onwards (fig. 3), the total hypophyseal LH content varied more than the concentration $(\mu \mathrm{g} / \mathrm{mg}$ ) of this hormone in both groups of animals.

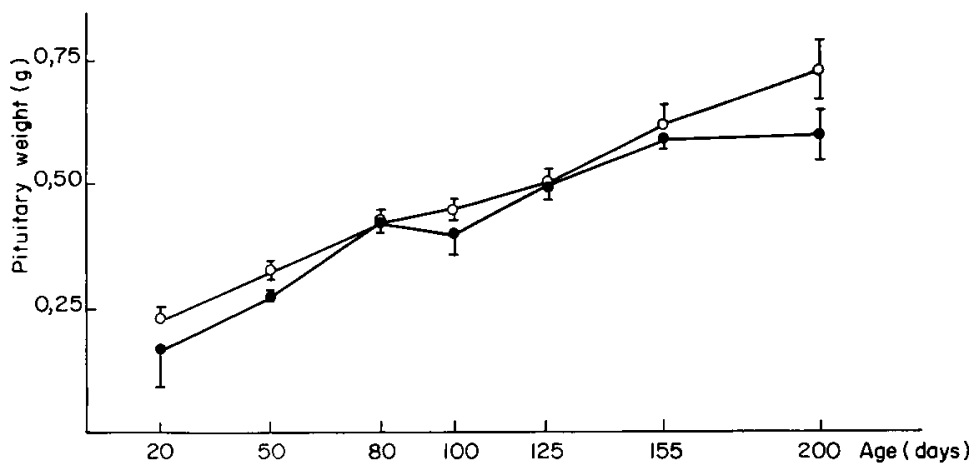

FIG. 3. - Increase in pituitary weight $\left(m \pm s_{e}\right)$ in lambs born in September (- - ) or February (o- - o)

\section{C. - LH in blood plasma}

LH was detectable soon after birth in the peripheral blood of the lamb (fig. 4). Thereafter, the mean level of LH increased linearly 3 to 4 times during the first two months after birth in both groups of lambs, independent of the season of birth, with a correlation coefficient of 0.92 and 0.95 between the weekly mean level of plasma LH and the age up to 63 and 70 days for lambs born in September and February respectively. At about $70-80$ days of age, plasma $L_{L} H$ tended to decrease, but the ratio of the mean $\mathrm{LH}$ at $125-\mathrm{I} 65$ days to the maximum $\mathrm{LH}$ at 63 or 70 days was higher in the February born lambs, 65 p. Ioo, than in those born in September, 33 p. IOO.

$$
\text { D. - Half-life of exogenous } L H
$$

The mean halving time of radioactivity attributible to the immunoprecipitable LH was $24 \mathrm{mn}$. The same measurement done on the crude blood plasma gave a slightly higher value of $29 \mathrm{mn}$, the three lambs reacting in the same way. 

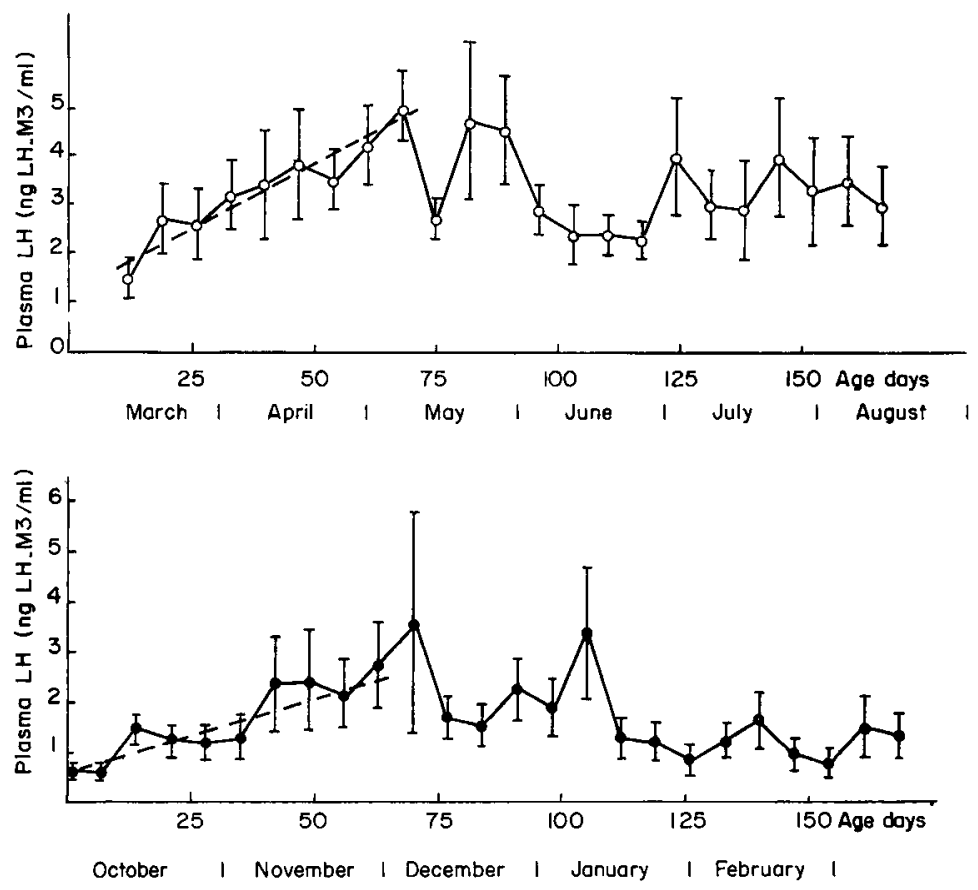

Fig. 4. - Plasma $L H$ concentration $\left(m \perp s_{e}\right.$ ) in lambs at different ages Age and month of sampling are given on the abcissa. Lambs born in September ( - ) or February $(0 \longrightarrow 0)$

\section{DISCUSSION}

The $\mathrm{LH}$ concentration in the lamb pituitary shows a large increase between birth and 80 days of age. This confirms the observations of SkINNER et al. (I968). This phenomenon is seasonally independent and the concentration at 80 days is significantly higher than that of the adult (PELLETIER, I97I). After 80 days, the pituitary content seemed to be related to the season of sampling, thus being secondarily dependent upon the birth season. The level of LH decreases rapidly in the February born lambs. For those born in Autumn, the decrease in LH commences at I55 days. Thus, the seasonal variation observed in the adult (PELLETIER and ORTAVANT, I967) occurs only after the pituitary content of LH reached the peak value observed at 3 months.

Contrary to what has been described in the human (see review by FAIMAN and WINTER, I974), in the chimpanzee (FAIMAN, REYES and WINTER, I974) and in the bull (Schams, BUTZ and KARG, I972 ; GIMENEZ et al., I974), where blood LH remains at a constant and low level throughout the impuberal period, but in agreement with observations made in the guinea pig (DOnOvan, TER HAAR and PEDdie, I974), we found in the lamb that the blood LH increases quite regularly from birth onwards to the 9-Ioth week of age, where it reaches a maximum regardless of the season. 
Then it decreases and stabilises at a relatively constant level between I25 and 200 days, being regulated by other factors, possibly seasonal ones, as shown by the ratio of the mean $\mathrm{L}_{4} \mathrm{H}$ at $125-165$ days to the maximum $\mathrm{LH}$ at 63 or 70 days. The initial increase in the blood plasma LH after birth has already been observed in the Prealpes and Romanov $\times$ Prealpes lambs (Thimonier, PeLLETIER and LAND, I972) and in Merino $\times$ Corriedale lambs, but for a shorter period (LEE et al., I974); however, it was not noticed in preliminary results on Ile-de-France lambs born in Autumn where plasma $\mathrm{LH}$ had been found relatively constant (CoURoT, de REVIERS and PELIETIER, I972). On the other hand, the frequency of blood sampling - once a week - in the present work did not allow the study of the daily or hourly variations in blood LH as recently demonstrated in the lamb by FosTER (I974). Such variations would probably explain the magnitude of the standard error and an exceptionnally elevated value $(23 \mathrm{ng} / \mathrm{ml})$ encountered in one sample of a 70 days old lamb. One may also point out that the mean levels noticed in the lamb are higher than those normally observed in the adult, whereas the half-life of the hormone, estimated by the disappearance from the blood of labelled $\mathrm{LH}$, is very close in the lamb (see the present results), and in the adult (GEschwind and DEWEy, r968; de KRETSER, AtKIns and PAULSEN, I973). Thus it appears that during the first two to three months after birth there is a simultaneous increase of LH in the pituitary and blood plasma. This is indicative of a high synthetic and release activity by the pituitary gland.

At the same time, testicular growth is very low (CovRo' I, I962), and it accelerates only after the pituitary concentration in $\mathrm{LH}$ reached its maximum and the blood plasma level has already decreased. The testicular development would thus appear to result from a previous hormonal stimulation. The more precocious testicular growth in Autumn born animals (fig. I) could be explained by a larger hormonal impulse in these lambs born in the sexual season where photoperiodism influences the neuroendocrine system more favorably (PELLETIER, I97I) than it does in lambs born in February. This is quite clear with the pituitary content in $\mathrm{LH}$ (fig. 2) even if it has not been demonstrated in the plasma. Technical difficulties may have contributed to this ; because of the large number of blood samples it had not been possible to carry out all the assays simultaneously. The seasonally modulated hormonal impulse would also explain the difference in testicular weight at 200 days of age : this is in the sexual season (September) for the February born animals and in the non sexual season (April) for those born in September. This is supported by the pituitary LH for the latter (fig. 2) and the higher relative blood plasma $\mathrm{LH}_{\mathrm{H}}$ for the former ( $\mathrm{I}_{\mathrm{H}} \mathrm{H}$ at $\mathrm{I}_{50} \mathrm{days}$ related to the peak at 70 days).

Testosterone has been assayed in the blood plasma samples of the September born lambs. It increased linearly during the first three months of life and is highly correlated with blood $\mathrm{L}_{\mathrm{H}} \mathrm{H}$ when the latter also increases linearly $(r=+0.85$, CotTA et al., I974). Similar studies reported by SANFord, PALMER and Howland (I974) dealt only with measurements beginning at an older age. On the other hand, hemicastration provided experimental evidence for a negative feed-back in the young lamb (Crim and Geschwind, I972; Foster, CoOk and Nalbandov, I972) and in the calf (ODEL, and KIDDY, I969). However, it has been shown that LH release in response to intravenous $\mathrm{L} R H$ injection was of the immature type before 60 days of age and changed to a mature type after 8O-Ioo days of age (GALLOWAY and PELLE- 
TIER, I974). The present results with the decrease in plasma LH in the third month of life, could be related to the maturation of the feed-back mechanism in the lamb which changes to the adult type and becomes sensitive to modulation by photoperiodisnl.

Recu pour publication en avril 1975.

\title{
ACKNOWLEDGMENTS
}

This work was supported mostly by the French National Institute for Agronomical Research (I. N. R. A.) and partly by the French Delegation for Scientific and Technical Research (D. G. R. S. T., grants 70.7 .2476 and 71.7 .3021 ). Comments and helpfull assistance in translation of the manuscript by Drs. BINDON and CLARKE are gratefully acknowledged.

\section{RÉSUMÉ}

\author{
ÉVOLUTION DE LA III HYPOPHYSAIRE ET SANGUINE \\ PENDANT LA PUBERTÉ CHEZ L'AGNEAU MÂLE. \\ RELATION AVEC LE MOMENT DE LA NAISSANCE
}

La concentration hypophysaire et la tencur du plasma sanguin périphérique en LH ont été mesurées chez des agneaux Ile-de-France nés pendant la saison sexuelle (septembre) ou en contresaison (février) pour voir si des modifications particulières intervenaient au moment de la puberté. Les résultats ont été reliés à ceux du développement testiculaire.

Au cours de la période de croissance testiculaire lente, période impubère vraie, il y a une forte augmentation de la charge hypophysaire en LH (6 à 7 fois), indépendante de la saison, et une augmentation linéaire significative de la teneur en LH du plasma sanguin ; la demi-vie de LH plasmatique est la même que celle observée chez l'aclulte. Dans la période de croissance testiculaire rapide, périodes prépubère et pubère, la concentration hypophysaire en LH est, selon la saison, stabilisée ou même en diminution. LH plasmatique, après le maximum observé à la fin de la période précédente, diminue et fluctue autour d'une valeur moyenne comparable à celle observée chez l'adulte. Ainsi, la spermatogenèse commence après que LH plasmatique ait atteint un maximum.

\section{REFERENCES}

Cotta Y., Teroui M., Pelletier J., Courot M., I975. Testostérone et LH plasmatiques chez l'Agneau de la naissance à la puberté. C. R. Acad. Sc., Paris, Série D, 280, 1473-I476.

Courot M., I962. Développement du testicule chez l'Agneau. Établissement de la spermatogenèse. Ann. Biol. anim. Bioch. Biophys., 2, 25-42.

Covrot M., I97o. Effect of gonadotropins on the seminiferous tubules of the immature testis. In The Human Testis, Adv. Exp. Med. Biol., 10,355-367, E. Rosemberg and C. A. Paulsen Edit., Plenum Press, New York.

Courot M., de Reviers M. M., Pelletier J., 1972. Pituitary and blood LH in the male lamb. J. Reprod. Fert., 31, 497-498.

CRIM L. W., Geschwind I. I., I972. Patterns of FSH and LH secretion in the developing ram : the influence of castration and replacement therapy with testosterone propionate. Biol. Reprod., 7, 47-54.

de Kretser D. M., Atkins R. C., Paulsen C. A., I973. Role of the kidney in the metabolism of luteinizing hormone. J. Endocr., 58, 425-434.

Donovan B. T., ter HaAR M. B., Peddie M. J., I974. Gonadal-pituitary interaction in the fotal and neonatal guinea pig. Int. Symp. on Sexual Endocrinology of the Perinatal Period, I. N.S. E. R. M., 32, I6I-I76. 
Faiman C., Winter J. S. D., i974. Gonadotropin and sex hormone patterns in puberty : clinical data. In Control of onset of Puberty, M. M. Grumbach, G. D. Grave, F. E. MAYer Édit., John Wiley and Sons, New York, 32-55.

Faiman C., Reyes F. I., Winter J. S. D., I974. Serum gonadotropin patterns during the perinatal period in man and in the Chimpanzee. Int. Symp. on Sexual Endocrinology of the Perinatal Period, I. N. S. E. R. M., 32, $28 \mathrm{I}-298$.

Foster D. L., 1974. Regulation of gonadotropins during fetal and early postnatal development in the sheep. Int. Symp. on Sexual Endocrinology of the Perinatal Period, I. N. S. E. R. M., 32, I43-I56.

Foster D. L., Cook B., Nalbandov A. V., I972. Regulation of luteinizing hormone (LH) in the fetal and neonatal lamb : effect of castration during the early postnatal period on levels of LH in sera pituitaries of neonatal lambs. Biol. Reprod., 6, 253-257.

Galloway D. G., Pelletier J., I974. Influence of age on the pituitary response of male lambs to synthetic LH-RH injection. Horm. Metab. Res., 6, 240-24I.

Geschwind I. I., Dewey R., 1968. Dynamics of luteinizing hormone (LH) secretion in the cycling ewe : a radioimmunoassay study. Proc. Soc. exp. Biol. Med., 129, 45I-455.

Gimenez T., Hoffmann B. Schams D., Hartl H., Schallenberger E., i974. Plasma levels of testosterone in relation to LH and FSH in bulls from birth through puberty. J. Steroid. Bioch., 5, Abstr. 369 .

Lee V. W. K., Cumming I. A., de Kretser D. M., Findlay J. K., Hudson B., Keogh G. J., 1974. Patterns of LH, ISH and testosterone levels in the developing ram. Proc. 6th ann. Conf. Austr. Soc. Repr. Biol. (Abstr. 7).

Odell W. D., KIDDY C. A., 1969. Prepubertal gonadal-pituitary luteinzing hormone (LH) interrelations. Clin. Res, 17 (Abstr.), I45.

Pelletier J., 1963. Étude critique du dosage de ICSH par la méthode de l'acide ascorbique ovarien. Ann. Biol. anim. Bioch. Biophys., 3, 307-323.

Pelletier J., I97I. Influence du photopériodisme et des androgènes sur la synthèse et la libération de LH chez le bélier. Thèse Doct. Sci., Paris, 243 p. C. N. R.S. AO $544 \mathrm{r}$.

Pelletier J, Ortavant R, 1967. Influence du photopériodisme sur les activités sexuelles, hypophysaire et hypothalamique du bélier Ile de France. In Photorégulation de la reproduction chez les Oiseaux et les Mammifères, I. Assenmacher and J. Benoit Édit., C. N. R. S. Publ., 483-493.

Pelletier J., Kann G., Dolais J., Rosselin G., i968. Dosage radioimmunologique de l'hormone lutéinisante plasmatique chez le Mouton. Mise au point de la technique de dosage. C. R. Acad. Sc., Paris, Sér. D, 266, $229 \mathrm{I}-2294$.

Sanford L. M., Palmer W. M., Howland B. E., I974. Seasonal variation of serum levels of LH and testosterone in the ram. Canad. J. Anim. Sci., 54, 247-249.

Schams D., Butz H. D., Karg H., 1972. Sex differences of plasma luteinizing hormone level from birth to puberty in the bovine. Acta Findocr. (Kbh), Suppl., 159, I Io.

Skinner J. D., Booth W. D., Rowson L. E. A., Karg H., I968. The post-natal development of the reproductive tract of the Suffolk ram, and changes in the gonadotrophin content of the pituitary J. Reprod. Fert., 16, $463-478$.

Thimonier J., Pelletier J., Land R. B., I972. The concentration of plasma LH in male and female lambs of high and low prolificacy breed types. J. Reprod. Fert., 31, 498-499.

Watson R. H., SAPSFord C. S., McCance I., I956. The development of the testis, epididymis and penis in the young merino ram. Aust. J. Agric. Res., 7, 574-590. 